\title{
SELF-COMPASSION AND RELATIONAL-INTERDEPENDENT SELF-CONSTRUAL
}

\author{
Ahmet AKIN ${ }^{1}$, Yüksel EROĞLU² \\ ${ }^{1}$ Faculty of Education, Department of Psychological Counseling and Guidance \\ Sakarya University, 54300 Hendek/Sakarya, Turkey \\ E-mail:aakin@sakarya.edu.tr \\ ${ }^{2}$ Faculty of Education, Department of Psychological Counseling and Guidance \\ Uludağ University, 16285 Görükle/Bursa, Turkey \\ E-mail: yeroglu45@gmail.com
}

\begin{abstract}
The aim of this research is to examine the relationships between self-compassion and relational-interdependent self-construal. The participants were 338 university students. In this study, the Self-Compassion Scale and the Relational-Interdependent Self-Construal Scale were used. The relationships between self-compassion and relational-interdependent self-construal were examined using correlation analysis and multiple regression analysis. In correlation analysis, self-kindness, common humanity, and mindfulness factors of self-compassion were found positively related to relational-interdependent self-construal. On the other hand, self-judgment, isolation, and over-identification factors of self-compassion were found negatively correlated to relational-interdependent self-construal. Multiple regression analysis showed that relationalinterdependent self-construal was predicted positively only by common humanity. However, relational-interdependent self-construal was negatively explained by isolation, self-judgment, and over-identification. According to standardized beta coefficients, the most significant predictor of relational-interdependent self-construal was isolation. Results were discussed in the light of the related literature.
\end{abstract}

Key words: self-compassion, relational-interdependent self-construal, multiple regression analysis

Self-compassion proposes an alternative view to thinking about psychological wellbeing. It is derived from Buddhist ideas over 2000 years old (Neff, Kirkpatrick, Rude, 2007) and involves being discerning and gentle towards oneself in the face of hardship or perceived inadequacy. It also entails acknowledging that suffering, failure, and inadequacies are part of the human condition and that all people - oneself included - are worthy of compassion (Neff et al., 2007). Neff $(2003 \mathrm{a}, \mathrm{b})$ has proposed that self-compassion includes three main components: self- kindness versus self-judgment, a sense of common humanity versus isolation, and mindfulness versus over-identification. While these three components of self-compassion are conceptually distinct and are experienced differently at the phenomenological level, they interact so as to mutually enhance and engender one another (Neff, 2003a).

Since self-compassion entails not being self-critical when one's expectations are not met and not being harmful to an individual's ego in order to gain achievements, suggest-

DOI: $10.21909 /$ sp.2013.02.629 
ing that the individual should encourage his/ her ego gently and patiently to change behaviors (Neff, 2009), thus, self-kindness, as being the most important aspect of self-compassion, refers to being kind and understanding toward oneself in instances of pain or failure rather than being harshly self-critical. Common humanity, the second dimension of self-compassion, is seeing one's happy or painful experiences as not personal, but shared by all human beings. The relation of common humanity principal to self-compassion involves recognizing that all humans are imperfect and that they fail and make mistakes (Neff, 2009). Having this kind of awareness, one perceives these experiences as part of the larger human experience rather than feeling isolated and alienated from the society and harshly criticizing oneself for failure and suffering experiences (Neff, 2003a). This awareness also emphasizes one's relatedness to all other humans and to another individual (Kirkpatrick, 2005). Mindfulness, the third component of self-compassion, is a preconceptual awareness that allows an individual to accept life's most stressful and painful emotions without being carried away by them (Gunaratana, 1993; Martin, 1997; Neff, 2003a; Nisker, 1998; Rosenberg, 1999). Mindfulness is a state of balanced awareness that one's feelings and thoughts are observed without avoiding or trying to change them, without exaggeration and prejudice. When individuals accept and tolerate their distress and pain, when they are gentle and kind toward themselves, they avoid suppressing their emotions and thoughts. Thus, when they are aware that distress and pain are something all humans experience, they are not trapped by over-identification. Therefore, self-compassion functions as an adaptive strategy for emotion-organizing through decreasing negative emotions and creating more positive emotions of kindness and relatedness (Neff, Hsieh, Dejitterat, 2005).

A developing line of research has documented numerous intrapersonal benefits of self-compassion and its relationships with psychological health. For example, self-compassion was found negatively associated with self-criticism, depression, anxiety, rumination, (Neff, 2003a; Deniz, Sümer, 2010), interpersonal cognitive distortions (Akin, 2010a), and loneliness (Akin, 2010b) and positively associated with social relationship, emotional intelligence, self-determination (Neff, 2003a), psychological well-being (Akin, 2008b), self-efficacy, and social identity (Williams, 2005). At the same time, selfcompassionate people are less likely to suppress unwanted thoughts and emotions and are more willing to acknowledge their negative emotions (Leary et al., 2007; Ne, 2003a; Neff et al., 2005). It has been found that these people ruminate less than those who lack self-compassion, are less perfectionistic (Neff, 2003a), and tend to experience fewer negative emotions such as irritability, hostility or distress (Neff, Rude, Kirkpatrick, 2007).

\section{Relational-Interdependent Self-Construal (RISC)}

Self-construal is defined as "the degree to which people see themselves as separate from others or as connected with others" (Markus, Kitayama, 1991, p. 226). Individuals vary in the manner in which they construct their self-construals. People in individualistic cultures possess higher levels of independent self-construal because their sense of self is constructed through autonomy from others. For them, the self is seen as distinct from others and their behaviors 
are motivated by advancing individual goals. On the other hand, people in collectivistic cultures possess higher levels of interdependence self-construal in which their self-concept is perceived through the lens of social connections and relationship with others (Markus, Kitayama, 1991; Van Baaren et al., 2003).

The type of interdependent self-construal constructed by individuals in collectivistic and individualistic culture is not the same (Kağıtçıbaşı, 2005). People in collectivist cultures are more likely to create an interdependent self-construal in terms of a membership within larger social relationships whereas people in individualistic cultures tend to do the same in terms of dyadic, close relationships. Thus, in individualistic cultures, interdependence is viewed in terms of a relational dimension (Kashima et al., 1995) and this form of interdependence is referred to as a relational-interdependent self-construal (Cross, Bacon, Morris, 2000).

Studies have demonstrated that relationalinterdependent self-construal is positively related with openness to relationships, responsive to needs and concerns of others (Cross et al., 2000), engaging in pro-relationship behaviors, communal strength (Mattingly, Oswald, Clark, 2011), help-seeking attitudes (Shea, Yeh, 2008), communal orientation (Bresnahan, Chiu, Levine, 2004), and relationship quality and negatively associated with hurting others' feelings, discrepancy, and self-dominance (Gendrin, 2010).

\section{The Present Study}

Although an increasing number of researchers have been examining the impact of self-compassion on individual function- ing, little research has examined its role in the context of interpersonal relationships. In their study, Crocker and Canevello (2008) found that people with self-compassion tended to have more compassionate goals in their close relationships, meaning that they tended to provide social support and encourage interpersonal trust with partners. Similarly, a study by Yarnell and $\mathrm{Ne}$ (2012) found that people who were high in self-compassion were more likely to resolve relationship conflicts with romantic partners. This may be due to self-compassion playing a determinative role in the ability to effectively balance the needs of self and the other in relationships. Self-compassion suggests an alternative to the more problematic construct of self-esteem (Neff, 2003b), which is linked to self-centeredness, distorted self-perceptions, downward social comparisons, and aggression under conditions of ego threat (Crocker, Park, 2004). And it was found positively related to extraversion, social connectedness (Neff, McGehee, 2010), and feeling interpersonally connected to others (Neff, 2003a, b). Because self-compassionate people were more likely to be authentic when resolving conflicts, suggesting that the constructive relationship behavior of self-compassionate individuals may yield personal as well as interpersonal benefits.

Thinking of oneself in terms of important relationships likely motivates people to maintain these relationships. Supportive of this idea, higher level of relational-interdependent self-construal is associated with having a greater number of close relationships, greater relationship satisfaction and commitment, and greater self-other overlap, exhibiting more self-disclosure in relationships, possessing more trusting and fullling relationships, paying greater attention to interper- 
sonal similarities, perceiving higher levels of social support from others, considering close others when making decisions, and understanding others' beliefs (Cross, Morris, Gore, 2002; Cross et al., 2000; Morry, Kito, 2009; Mattingly et al., 2011). Similarly, relationalinterdependent self-construal, which refers to conceiving of one's self in terms of one's social relationships, was found related positively to openness to relationships, responsive to needs and concerns of others (Cross et al., 2000), communal strength (Mattingly et al., 2011), communal orientation (Bresnahan, Chiu, Levine, 2004), and relationship quality.

The current study examines the relationships between self-compassion and relational-interdependent self-construal. As explained above, both self-compassion and relational-interdependent self-construal are positively related to adaptive interpersonal variables. Thus it might be assumed that mindfulness, self-kindness, and common humanity (adaptive dimensions of self-compassion) would be associated positively with relational-interdependent self-construal. On the other hand, it also might be assumed that self-judgment, isolation, and over-identification (maladaptive dimensions of self-compassion) would be related negatively to relational-interdependent self-construal.

\section{METHOD}

\section{Participants}

Participants were 338 university students $(158$ (46\%) were female and $180(54 \%)$ were male) enrolled in various undergraduate programs at Sakarya University Faculty of Education, Turkey. Of the participants, $74(22 \%)$ were first-year students, 78 (23\%) were sec- ond-year students, 90 (27\%) were third-year students, and 96 (28\%) were fourth-year students. Their ages ranged from 17 to 30 years old (20.65 \pm 1.18$)$.

\section{Measures}

Self-Compassion Scale. Self-compassion was measured by using the Self-Compassion Scale (Neff, 2003b). Turkish adaptation of this scale was done by Akin, Akin, and Abaci (2007). The Self-Compassion Scale is a 26item self-report measurement and consists of six sub-scales; self-kindness (5 items, e.g., I try to be loving towards myself when I'm feeling emotional pain), self-judgment (5 items, e.g., When times are really difficult, I tend to be tough on myself), common humanity (4 items, e.g., I try to see my failings as part of the human condition), isolation (4 items, e.g., When I fail at something that's important to me, I tend to feel alone in my failure), mindfulness (4 items, e.g., When something upsets me I try to keep my emotions in balance), and over-identification (4 items, e.g., When I'm feeling down I tend to obsess and fixate on everything that's wrong). Each item was rated on a 5-point Likert scale $(1=$ strongly disagree to $5=$ strongly agree). Language validity findings indicated that correlations between Turkish and English forms were .94, .94, .87, .89, .92, and .94 for six subscales, respectively. Results of confirmatory factor analysis indicated that the model was well fit. The goodness of fit index values of the model were RMSEA $=.056, \mathrm{NFI}=.95, \mathrm{CFI}=.97, \mathrm{IFI}=.97$, $\mathrm{RFI}=.94, \mathrm{GFI}=.91$, and $\mathrm{SRMR}=.059$. The internal consistency coefficients were .77, $.72, .72, .80, .74$, and .74 and the test-retest reliability coefficients were $.69, .59, .66, .60$ .69 , and .56 , for six subscales, respectively. 
Relational-Interdependent Self-Construal Scale (RISCS; Cross et al., 2000). The RISCS was designed to assess the degree to which important relationships are incorporated into the self-concept. Turkish adaptation of this scale was done by Akin, Eroğlu, Kayiş, and Satici (2010). The RISCS is an 11item (e.g., My close relationships are an important reflection of who I am) measure containing nine positively worded items and two negatively worded items. Participants indicated the degree to which they agree with each item on the RISCS using a 7-point Likerttype scale ranging from 1 (strongly disagree) to 7 (strongly agree). The possible range of scores is from 11 to 77 . Higher scores indicate higher levels of RISCS. The Cronbach alpha reliability coefficient of the Turkish version was found as .85 .

\section{Procedure}

Permission for participation of students was obtained from related chief departments and students voluntarily participated in this research. Completion of the scales was anonymous and there was a guarantee of confidentiality. The scales were administered to the students in groups in the classrooms. The measures were counterbalanced in administration. Prior to administration of measures, all participants were told about the purposes of the study.

\section{Statistical Analysis}

In this research, multiple linear regression analysis and Pearson correlation coefficient were used to investigate the relationships between self-compassion and relational-interdependent self-construal. The variables, which were entered in multiple regression analysis, were measured by summing the items of each scale. These analyses were carried out via SPSS 11.5.

\section{RESULTS}

\section{Descriptive Data and Inter-Correlations}

Table 1 shows the means, descriptive statistics, inter-correlations of the variables.

When Table 1 is examined, it is seen that relational-interdependent self-construal was

Table 1. Descriptive statistics and inter-correlations of the variables

\begin{tabular}{|l|c|c|c|c|c|c|c|}
\hline Variables & 1 & 2 & 3 & 4 & 5 & 6 & 7 \\
\hline 1.Self-kindness & & & & & & & \\
\hline 2.Self-judgment & $-.60^{* *}$ & & & & & & \\
\hline 3.Common humanity & $.74^{* *}$ & $-.62^{* *}$ & & & & & \\
\hline 4.Isolation & $-.58^{* *}$ & $.72^{* *}$ & $-.63^{* *}$ & & & & \\
\hline 5.Mindfullness & $.70^{* *}$ & $-.61^{* *}$ & $.70^{* *}$ & $-.50^{* *}$ & & & \\
\hline 6.Over-identification & $-.62^{* *}$ & $.75^{* *}$ & $-.60^{* *}$ & $.70^{* *}$ & $-.64^{* *}$ & & \\
\hline 7.RISC & $.53^{* *}$ & $-.50^{* *}$ & $.59^{* *}$ & $-.51^{* *}$ & $.48^{* *}$ & $-.50^{* *}$ & \\
\hline Mean & 20.32 & 8.82 & 16.48 & 7.37 & 16.58 & 6.97 & 64.33 \\
\hline Standard deviation & 3.33 & 3.21 & 2.99 & 2.80 & 2.85 & 3.03 & 8.19 \\
\hline
\end{tabular}

** $\mathrm{p}<.01$ 
related positively to self-kindness $(\mathrm{r}=.53)$, common humanity $(\mathrm{r}=.59)$, and mindfulness $(\mathrm{r}=.48)$. On the other hand, relational-interdependent self-construal was found related negatively with self-judgment $(\mathrm{r}=-.50)$, isolation $(\mathrm{r}=-.51)$, and over-identification $(\mathrm{r}=$ $-.50)$.

\section{Multiple Regression Analysis}

Before applying regression, assumptions of multiple regression were checked. The data were examined for normality by the Kolmogorov-Smirnov test. The KolmogorovSmirnov test indicated normality of distributions of test scores for all tests in the current study. Outliers are cases that have data values that are very different from the data values for the majority of cases in the data set. Outliers were investigated using the Mahalanobis distance. A case is an outlier if the probability associated with its $\mathrm{D}^{2}$ is .001 or less (Tabachnick, Fidell, 2001). Based on this criterion, nineteen data were labeled as outliers and they were deleted. Multi-collinearity was checked by the variance inflation factors (VIF). All the VIF values were less than 10 (Tabachnick, Fidell, 2001), which indicated that there was no multi-collinearity.

Multiple regression analysis was performed in which the dependent variable was relational-interdependent self-construal and the independent variables were dimensions of self-compassion (Table 2). As many of those predictor variables were dependent on each other, a forward stepwise procedure was used, which includes one new explanatory variable at each step, specifically the most associated with the dependent variable while being, at the same time, independent of the explanatory variables already included in the model (Carchini et al., 2007). The criteria to include the variables from the regression

Table 2. Summary of forward stepwise multiple regression analysis for variable predicting relational-interdependent self-construal

\begin{tabular}{|c|c|c|c|c|}
\hline Variables & $B$ & $\begin{array}{c}\text { Standard Error } \\
\text { of B }\end{array}$ & $\beta$ & $t$ \\
\hline \multicolumn{5}{|l|}{ Step 1} \\
\hline Isolation & -2.08 & .14 & -.64 & $-14.27^{*}$ \\
\hline \multicolumn{5}{|l|}{ Step 2} \\
\hline Isolation & -1.48 & .18 & -.46 & $-8.23 *$ \\
\hline Common humanity & .82 & .16 & .29 & $5.27 *$ \\
\hline \multicolumn{5}{|l|}{ Step 3} \\
\hline Isolation & -1.24 & .19 & -.38 & $-6.58 *$ \\
\hline Common humanity & .60 & .16 & .21 & $3.65 *$ \\
\hline Self-judgment & -.53 & .15 & -.20 & $-3.58 *$ \\
\hline \multicolumn{5}{|l|}{ Step 4} \\
\hline Isolation & -1.16 & .19 & -.36 & $-6.07 *$ \\
\hline Common humanity & .52 & .17 & .18 & $3.10^{*}$ \\
\hline Self-judgment & -.37 & .16 & -.14 & $-2.27 *$ \\
\hline Over-identification & -.38 & .18 & -.13 & $-2.16^{*}$ \\
\hline
\end{tabular}

$* \mathrm{p}<.05$ 
model were: criterion probability-of-F-to enter $<.05$.

According to the results of multiple regression analysis, summarized in Table 2, isolation entered the equation first, accounting for $42 \%$ of the variance in predicting relational-interdependent self-construal $\left(\mathrm{R}^{2}=.42\right.$, adjusted $\left.\mathrm{R}^{2}=.41, \mathrm{~F}(1,281)=203.75, \mathrm{p}<.05\right)$. Common humanity entered on the second step accounting for an additional $5 \%$ of variance $\left(\mathrm{R}^{2}=.47, \underline{\Delta} \mathrm{R}^{2}=.05\right.$, adjusted $\mathrm{R}^{2}=.47$, $\mathrm{F}(1,280)=27.83, \mathrm{p}<.05)$. Self-judgment entered on the third step accounting for an additional $2 \%$ of variance $\left(\mathrm{R}^{2}=.49, \underline{\Delta} \mathrm{R}^{2}=.02\right.$, adjusted $\left.\mathrm{R}^{2}=.49, \mathrm{~F}(1,279)=12.84, \mathrm{p}<.05\right)$. Over-identification entered last, accounting for an additional $1 \%$ of variance $\left(\mathrm{R}^{2}=.50\right.$, $\underline{\Delta} \mathrm{R}^{2}=.01$, adjusted $\mathrm{R}^{2}=.50, \mathrm{~F}(1,278)=4.68$, $\mathrm{p}<.05)$. The initial regression design included mindfulness, common humanity, selfkindness, over-identification, isolation, and self-judgment as independent variables, however, the last regression models involved isolation, common humanity, self-judgment, and over-identification as predictors of relational-interdependent self-construal and accounted for $50 \%$ of the variance. The standardized beta coefficients indicated the relative influence of the variables in the last model with isolation $(\beta=-.36, p<.05)$, common humanity $(\beta=.18, \mathrm{p}<.05)$, self-judgment $(\beta=-.14, p<.05)$, and over-identification $(\beta=-.13, p<.05)$, all significantly influencing relational-interdependent selfconstrual, isolation being the strongest predictor.

\section{DISCUSSION}

The aim of this research was to investigate the relationships between self-compassion and relational-interdependent self- construal. Findings demonstrated that there are significant relationships between these two variables. Firstly, the most prominent finding was that isolation was the strongest predictor of relational-interdependent selfconstrual when compared to the other dimensions of self-compassion. Feeling of isolation occurs when people forget that failure and imperfection are part of the shared human experiences and it serves to amplify and enhance suffering (Neff, Beretvas, 2012). Similarly, those who lacked self-compassion were described as being significantly more controlling and domineering in their relationships. Thus, feelings of isolation may also be directly contributing to lessened relationship satisfaction. On the contrary, relationalinterdependent self-construal is associated with relational strengths such as having a greater number of close relationships, greater self-other overlap, and greater relationship satisfaction, possessing more trusting relationships, perceiving higher levels of social support from others, considering close others when making decisions, and understanding others' beliefs (Cross et al., 2000, 2002; Mattingly et al., 2011; Morry, Kito, 2009). Feeling isolated, therefore, appears to be linked negatively, to the relational-interdependent self-construal.

Secondly, common humanity predicted relational-interdependent self-construal positively. Common humanity represents "seeing one's experiences as part of the larger human experience" (Neff, 2003a, p. 7). People with common humanity do not meet the need for positive feelings by separating themselves from others but rather by incorporating appreciation of shared humanity into self-attitudes and treating oneself as others deserve to be treated (Neffet al., 2005). Also, to be able to have a feeling of common hu- 
manity allows individuals to accept themselves as they are, to act in accordance with their inner thoughts and values (Neff, 2003a; Neff et al., 2005), and to assert themselves in an authentic manner in their relationships. When thorny relationship issues arise, feeling of common humanity may enable them to soothe and calm the intensity of their emotions (Yarnell, Neff, 2012), so that they can respond to conflicts more peacefully (Kelly, Zuroff, Shapira, 2009). Similarly, results indicated that greater feeling of common humanity was linked to a greater sense of well-being within relationships. In parallel to this, relational-interdependent self-construal, viewing one's self-concept in terms of important close relationships, may be associated with more positive, adaptive, and longlasting relationships. Individuals whose selfconstruals are largely relationally-oriented are inclined to consider their close relationships in terms of communal endeavors, which are associated with selfless and pro-social behavioral patterns (Mattingly et al., 2011). Thus, the greater relational-interdependent self-construal is likely related to increased feeling of common humanity.

Thirdly, self-judgment predicted relationalinterdependent self-construal negatively. Self-judgment involves being hostile, demeaning, and critical to one's self or aspects of one's self (Neff, 2003a). People who are self-judgmental not only reject their own feelings, thoughts, impulses, actions, and worth but they tend to feel ashamed of their faults and to retreat from others. Instead of staying in contact with others, sharing their struggles or observing that others have similar struggles, they might be more likely to withdraw and believe that they alone struggle with flaws or failures (Neff, 2003b). The sense of care and connectedness provided by self- kindness is not only associated with greater emotional well-being more generally (Neff, 2009) but also greater well-being within the context of interpersonal relationships (Neff, Beretvas, 2012; Yarnell, Neff, 2012). Being self-critical and ruminating on the negative self-related emotions may lead to a type of self-absorption that blocks intimacy and connection in relationships. This may stem from the reality that when people are hard on themselves, they also tend to be harder on relationship partners. This interpretation is supported by the finding that people who lacked self-kindness were described as being significantly more verbally aggressive towards their partners (Neff, Beretvas, 2012). Similarly, relational-interdependent selfconstrual promotes relational cognition, which refers to the notion that one's connectedness is a primary focus of consciousness that leads to an awareness of others' behavior (Gendrin, 2010). In this context, it can be claimed that people who feel connected to others may judge themselves less harshly for weaknesses as they accept being imperfect is part of being human (Barnard, Curry, 2011). As a result, it is not surprising that there is a negative relationship between self-judgment and relational-interdependent self-construal.

Fourthly, over-identification predicted relational-interdependent self-construal negatively. Over-identification involves ruminating one's own limitations (Barnard, Curry, 2011; Neff et al., 2007) and leads to tunnel vision in which people become identified with and carried away by negative thoughts and feelings about themselves (Neff, Vonk, 2009). The emotional resilience and equilibrium destroyed by over-identification is damaging to constructive responses to relationship conflicts and problems, thereby decreas- 
ing psychological health within relationships. Because over-identification prevents an interdependent mode of being, it is likely that over-identified individuals are not better able to balance needs for connectedness in their relationships and this situation affects negatively the healthy and productive relationship interactions (Neff, Beretvas, 2012). In this context, it can be claimed that they might miss opportunities for connecting with others on a deeper level (Neff, 2003a). On the other hand, relational-interdependent selfconstrual has positive influences on openness to relationships, responsive to needs and concerns of others (Cross et al., 2000), and relationship quality. These relational patterns may be the causes of the negative association of over-identification with relational-interdependent self-construal.

This study makes several contributions. First, to our knowledge, it is the first to examine the relationships between self-compassion and relational-interdependent selfconstrual. People high in self-kindness, common humanity, and mindfulness are more likely to be high in relational-interdependent self-construal. Nonetheless, research both on self-compassion and relational-interdependent self-construal is still in its nascent phases and more research will need to be done before any absolute inferences can be drawn. Finally, based on findings of this study, it can be claimed that relationships between self-compassion and relational-interdependent self-construal support the view that self-caring and connectedness may be mutually supportive rather than opposites (Neff et al., 2005).

Although this study makes several contributions, it is extremely important to note that there are limitations to this study. First, participants were university students and repli- cation of this study for targeting other student populations should be made in order to generate a more solid relationship among the constructs examined in this study, because generalization of the results is somewhat limited. Second, as correlational statistics were utilized, no definitive statements can be made about causality. And last, the data reported here for self-compassion and relational-interdependent self-construal are limited to self-reported data.

Received April 30, 2012

\section{REFERENCES}

AKIN, Ü., AKIN, A., ABACI, R., 2007, Selfcompassion Scale: The study of validity and reliability. Hacettepe University Journal of Education, 33, 1-10.

AKIN, A., 2008b, Scales of Psychological Wellbeing: A study of validity and reliability. Educational Science: Theory \& Practice, 8, 3, 721-750.

AKIN, A., 2010a, Self-compassion and interpersonal cognitive distortions. Hacettepe University Journal of Education, 39, 1-9.

AKIN, A., 2010b, Self-compassion and loneliness. International Online Journal of Educational Sciences (IOJES), 2, 3, 702-718.

AKIN, A., EROĞLU, Y., KAYIŞ, A.R., SATICİ, S.A., 2010, The validity and reliability of the Turkish version of the Relational-Interdependent Selfconstrual Scale. Procedia-Social and Behavioral Sciences, 5, 579-584.

BARNARD, L.K., CURRY, J.F., 2011, Self-compassion: Conceptualizations, correlates, \& interventions. Review of General Psychology, 15, 4, 289303.

BRESNAHAN, M.J., CHIU, H.C., LEVINE, T.R., 2004, Self-construal as a predictor of communal and exchange orientation in Taiwan and the United States. Asian Journal of Social Psychology, 7, 187203.

CARCHINI, G., BELLA, V.D., SOLIMINI, A.G., BAZZANTI, M., 2007, Relationships between the presence of odonate species and environmental characteristics in lowland ponds of central Italy. International Journal of Limnology, 43, 2, 8187. 
CROCKER, J., CANEVELLO, A. 2008, Creating and undermining social support in communal relationships: The role of compassionate and self-image goals. Journal of Personality and Social Psychology, 95, 555-575.

CROCKER, J., PARK, L.E., 2004, The costly pursuit of self-esteem. Psychological Bulletin, 130, 392-414.

CROSS, S.E., BACON, P.L., MORRIS, M.L., 2000, The relational-interdependent self-construal and relationships. Journal of Personality and Social Psychology, 78, 4, 791-808.

CROSS, S.E., MORRIS, M.L., GORE, J.S., 2002, Thinking about oneself and others: The relationalinterdependent self-construal and social cognition. Journal of Personality and Social Psychology, 82, 3, 399-418.

DENIZ, M.E., SÜMER, A.S., 2010, The evaluation of depression, anxiety, and stress in university students with different self-compassion levels. $E d u$ cation and Science, 35, 158, 115-127.

GENDRIN, D.M., 2010, Relational-interdependent self-construal, imagined interactions, and conversational constraints among Vietnamese Americans. Intercultural Communication Studies, 19, 1, 10-28.

GUNARATANA, V.H., 1993, Sati. In mindfulness in plain English. Somerville, MA: Wisdom Publications.

KAGITÇIBAŞI, Ç., 2005, Autonomy and relatedness in cultural context. Journal of Cross-Cultural Psychology, 36, 4, 403-422.

KASHIMA, Y., YAMAGUCHI, S., KIM, U., CHOI, S.C., GELFAND, M.J., YUKI, M., 1995, Culture, gender, and self: A perspective from individualism-collectivism research. Journal of Personality and Social Psychology, 69, 925937.

KELLY, A.C., ZUROFF, D.C., SHAPIRA, L.B. 2009, Soothing oneself and resisting self-attacks: The treatment of two intrapersonal deficits in depression vulnerability. Cognitive Therapy and Research, 33, 301-313.

KIRKPATRICK, K.L., 2005, Enhancing selfcompassion using a Gestalt two-chair intervention, Unpublished doctoral dissertation, University of Texas at Austin.

LEARY, M.R., TATE, E.B., ADAMS, C.E., ALLEN, A.B., HANCOCK, J., 2007, Self-compassion and reactions to unpleasant self-relevant events: The implications of treating oneself kindly. Journal of Personality and Social Psychology, 92, 887 904.
MARKUS, H., KITAYAMA, S., 1991, Culture and the self: Implications for cognition, emotion and motivation. Psychological Review, 98, 224-253.

MARTIN, J.R., 1997, Mindfulness: A proposed common factor. Journal of Psychotherapy Integration, 7, 291-312.

MATTINGLY, B.A., OSWALD, D.L., CLARK, E.M., 2011, An examination of relationalinterdependent self-construal, communal strength, and pro-relationships behaviors in friendships. Personality and Individual Differences, 50, 12431248.

MORRY, M.M., KITO, M., 2009, Relationalinterdependent self-construal as a predictor of relationship quality: The mediating roles of one's own behaviors and perceptions of the fulfillment of friendship functions. Journal of Social Psychology, 149, 205-222.

NEFF, K.D., 2009, Self-compassion. In: M.R. Leary, R.H. Hoyle (Eds.), Handbook of individual differences in social behavior (pp. 561-573). New York: Guilford Press.

NEFF, K.D., 2003a, Self-compassion: An alternative conceptualization of a healthy attitude toward oneself. Self and Identity, 2, 2, 85-102.

NEFF, K.D., 2003b, The development and validation of a scale to measure self-compassion. Self and Identity, 2, 3, 223-250.

NEFF, K.D., BERETVAS, S.N., 2012, The role of self-compassion in romantic relationships. Self and Identity, 1-21.

NEFF, K.D., HSIEH, Y., DEJITTERAT, K., 2005, Self-compassion, achievement goals, and coping with academic failure. Self and Identity, 4, 263287.

NEFF, K.D., KIRKPATRICK, K.L., RUDE, S.S., 2007, Self-compassion and adaptive psychological functioning. Journal of Research in Personality, 41, 139-154.

NEFF, K.D., MCGEEHEE, P., 2010, Self-compassion and psychological resilience among adolescents and young adults. Self and Identity, 9, 225240 .

NEFF, K.D., RUDE, S.S., KIRKPATRICK, K., 2007 , An examination of self-compassion in relation to positive psychological functioning and personality traits. Journal of Research in Personality, 41, 908-916.

NEFF, K.D., VONK, R., 2009, Self-compassion versus global self-esteem: Two different ways of relating to oneself. Journal of Personality, 77, 23-50.

NISKER, W., 1998, Mindfulness: The opposable thumb of consciousness (Chapter 3). In: Buddha's 
nature: A practical guide to discovering your place in the cosmos (pp. 26-30). New York: Bantam Books. ROSENBERG, L., 1999, Breathing with the body (Chapter 1). In: Breath by breath: The liberating practice of insight meditation (pp. 10-39). Boston: Shambala.

SHEA, M., YEH, C.J., 2008, Asian American students' cultural values, stigma, and relational-interdependent self-construal: Correlates of attitudes toward professional help seeking. Journal of Mental Health Counseling, 30, 157-172.

TABACHNICK, B.G., FIDELL, L.S., 2001, Using multivariate statistics. Boston: Allyn and Bacon.
VAN BAAREN, R.B., MADDUX, W.W., CHARTRAND, T.L., BOUTER, C., KNIPPENBERG, A., 2003, It takes two to mimic: Behavioral consequences of self-construals. Journal of Personality and Social Psychology, 84, 5, 1093-1102.

WILliaMS, J.G., 2005, Forewarning: A tool to disrupt stereotype threat effects. Unpublished doctoral dissertation, University of Texas at Austin, TX, USA.

YARNELL, L., NEFF, K.D., 2012, Self-compassion, interpersonal conflict resolutions, and wellbeing. Self and Identity, 1-14.

\title{
SEBALÚTOSŤ A VZŤAHOVO-INTERDEPENDENTNÝ KONŠTRUKT SELF
}

\begin{abstract}
A. A k in, Y. E ro ğ $1 \mathrm{u}$
Súhrn: Zámerom výskumu je preskúmat' vzt'ah medzi sebalútost'ou a vzt’ahovointerdependentným konštruktom self. Respondentmi bolo 338 univerzitných študentov. V tejto štúdii sa použili Self-Compassion Scale a Relational-Interdependent Self-Construal Scale. Vzt'ahy medzi sebalútost'ou a vzt’ahovo-interdependentným konštruktom self sme skúmali pomocou korelačnej analýzy a viacnásobnej regresnej analýzy. Korelačná analýza ukázala pozitívny vzt’ah medzi láskavost'ou voči sebe, bežnou l'udskost'ou a uvedomelost'ou a vzt'ahovo-interdependentným konštruktom self. Na druhej strane, sebaodsudzovanie, izolácia a prílišná identifikácia korelovali s vzt’ahovo-interdependentným konštruktom self negatívne. Viacnásobná regresná analýza ukázala, že vztahovo-interdependentný konštrukt self bol pozitívne predikovaný iba bežnou l'udskost'ou. Vzt’ahovo-interdependentný konštrukt self však negatívne charakterizovali izolácia, sebaodsudzovanie a prílišná identifikácia. Podl'a štandardizovaných beta koeficientov bola najsignifikantnejším prediktorom vzt'ahovo-interdependentného konštruktu self izolácia. Výsledky sme konfrontovali s relevantnou literatúrou.
\end{abstract}

